\title{
ЛОГІЧНИЙ АНАЛІЗ ТЕКСТУ ЯК ПОЧАТКОВИЙ ЕТАП НАВЧАННЯ СЦЕНІЧНОЇ МОВИ ПЕРШОКУРСНИКІВ
}

\author{
(на прикладі уривків з кіноповісті О. Довженка «Зачарована Десна»)
}

\begin{abstract}
Стаття присвячена логічному аналізу тексту 一 як одному із початкових етапів навчання для студентів-першокурсників - на прикладі уривків із кіноповісті О. Довженка «Зачарована Десна». Досліджено проблему переходу студента від побутового мовлення до набуття майстерності художнього відтворення тексту, володіння голосово-мовленнєвим апаратом.
\end{abstract}

Ключові слова: сиенічна мова, логічний аналіз, прозовий уривок, словесна дія, студент-першокурсник.

Статья посвящена логическому анализу текста - как одному из начальных этапов обучения студентов-первокурсников - на примере отрывков из киноповести А. Довженко «Зачарована Десна», Исследована проблема перехода студента от бытовой речи к приобретению мастерства художественного воспроизведения текста, владение голосово-речевым аппаратом.

Ключевые слова: сиеническая речь, логический анализ, прозаический отрывок, словесное действие, студент-первокурсник.

The article is devoted to the logical analysis of the text as one of the initial stages of training for firstyear students, on the example of excerpts from the movie story by $O$. Dovzhenko "Zacharovana Desna». The problem of student transition from everyday speech to the acquiring skills of artistic reproduction of the text, possession of the voice and speech machine was studied.

Key words: scenic language, logical analysis, prose excerpt, verbal action, first-year student.

Мета статті - на конкретних прикладах 3 художнього прозового твору, а саме кіноповісті О. Довженка «Зачарована Десна», продемонструвати процес оволодіння основними навичками логічного розбору тексту для подальшого осмисленого читання актором під час публічного виступу.

Методологія дослідження полягає у застосуванні практичного, структурного, аналітичного, функціонального методів дослідження під час вивчення особливостей навчальної діяльності студентів-першокурсників, майбутніх акторів. Наукова новизна дослідження визначається тим, що ці методологічні розвідки сприятимуть вирішенню конкретних практичних завдань у професійному навчанні й сприятимуть усуненню наявних мовленнєвих недоліків студентів-першокурсників. Конкретно представлені уривки нададуть студентам-першокурсникам предметну демонстрацію.

Висновки: Освоєння правил логіки сценічної мови вимагає уваги й часу. Треба, щоб студенти добре освоїли правила логічного аналізу сценічної мови й навчилися застосовувати їх на практиці так, щоб це стало «другою натурою» кожного студента, майбутнього актора. На прикладі одного літературного твору, який часто обирають студенти для самостійного опрацювання, можна показати великий спектр різноманітних засобів, які допомагають передати думку авторського тексту, власну оцінку, смислові інтонації, що втілюються через словесну дію. Студентам не слід боятися певних закономірностей і виведених правил.

Ключові слова: сценічна мова, студент-першокурсник, логічний аналіз, художнє слово.

У зв'язку зі стрімким розвитком аудіовізуального мистецтва попит на фахівиів - носіїв якісного мовлення, зростає. Сценічна мова - ие елемент зовнішньої техніки актора, тож має підпорядковуватися сучасним вимогам: вона має набувати більшої природності й давати можливість якісно виражати думки й почуття зі ще 
більшим ступенем сили, виразності, точності, дохідливості й краси, ніж у повсякденні. Украӥнському мовленню притаманна мелодійність. Та, на жаль, дедалі частіше з телеекранів чи з ефірів радіостаниій можна почути «з 'їдання» голосних звуків, «жування» приголосних тощо. Тому на першому етапі навчання студентів: акторів, медійників, теле-радіоведучих тощо, слід приділяти максимум зусиль для набуття майстерності художнього відтворення текстів.

Уміння доносити зміст у мовленні-це можливість передавати у звучанні думку автора, закладену у тексті ролі, медіа-повідомленні тощо, котра допомагає так організувати текст, щоб усвідомлено впливати на глядача/слухача.

Ми розглянемо головні аспекти вивчення логічного аналізу на прикладі одного твору: кіноповісті О.П. Довженка «Зачарована Десна», адже досить часто студенти обирають для читання на залік зі сценічної мови уривки саме з цього твору. Також уривки кіноповісті є рекомендованими для читання абітурієнтами під час відбіркових консультацій і творчих заліків.

Питання логічного аналізу текстів сценічної мови докладно розглядала у статті «Сценічна мова» А. О. Гладишева [1]. Також це питання було предметом дослідження провідного викладача Щукінського театрального училища Т. I. Запорожець, яка детально дослідила логіку сценічного тексту як основу навчання першокурсників [2]. Методологічні аспекти формування навичок сценічного читання в роботі над літературним твором розглядала і Т. Д. Петрик, викладачка Запорізького національного університету, яка зазначала: «Процес оволодіння літературним матеріалом будь-якого жанру називається роботою над текстом; кінцевий результат такої роботи - народження яскравого, виразного, емоційного художнього слова» [3].

Логічний аналіз тексту, що його читає актор, $\epsilon$ початком, фундаментом роботи над текстом, засобом виявлення акторської думки. Розуміння твору, передача його читачам неможливі без проникнення у внутрішній світ письменника, без розуміння й ставлення до того, про що він пише. Це перший, підготовчий етап роботи над текстом. Якщо виконавець буде налаштований лише на власне бачення емоційної сфери, то він не зможе передати всю гармонію почуттів і всі ланки подієвого ланцюга. На нашу думку, логічний аналіз тексту, що його читає актор чи диктор, є початком, фундаментом роботи над текстом, засобом виявлення акторської думки. Ми розглядаємо цей процес так (див. рис. 1).

Звернемося до прикладів. В уривкові з твору О. Довженка «-Нічого в світі так я не люблю, як саджати що-небудь у землю, щоб проізростало. Коли вилізає з землі всяка рослиночка, ото мені радість,-любила проказувати вона» [4], треба прочитати текст далі, щоб дізнатися зміст усього твору. Автор за допомогою однієї репліки показує, якою щирою, доброю, працьовитою була героїня, як маленький Сашко захоплювався своєю матір'ю, iї любов'ю до землі й до праці. Як бачимо, можна визначити словесну дію: засуджувати, хвалити, висміювати, співпереживати тощо. Кожен текст має певні логічні наголоси та логічні паузи. Речення ділиться на групи, що складаються з одного або декількох слів - тактів. Як відомо, є група підмета, група присудка, група обставин і т.п. У мовленнєвому такті є слово, що виділяється підвищенням, пониженням або посиленням звуку голосу. Таке виділення називається логічним наголосом. Окремий мовленнєвий такт, як правило, не містить закінченої думки. Наголоси кожного такту мають бути підпорядковані головному наголосу речення. Кожен мовленнєвий такт має бути виділений логічними паузами (зупинками голосу та зміною висоти голосу). Це посилює інтонаційну різноманітність акторського мовлення. Усередині мовленнєвого такту можуть бути паузи, всі слова, що містяться у мовленнєвому такті, промовляються разом, майже одним словом.

Часто на письмі такти розділені комами чи іншими розділовими знаками, хоча поділ за розділовими знаками є дещо умовним, бо логічних пауз може бути більше. Крім того, не варто забувати про люфтпаузи (паузи добору повітря) та психо-

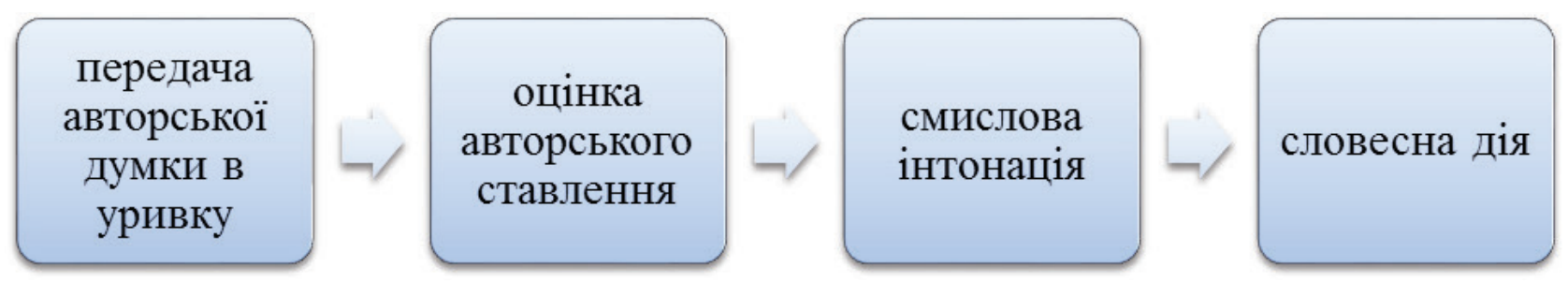

Рис. 1 
логічні паузи. Як зазначив К.С. Станіславський: «Беріть частіше книгу, олівець, читайте і розмічайте прочитане по мовних тактах. Набийте собі на цьому вухо, око й руку <...> Розмітка мовних тактів і читання по них необхідні тому, що вони змушують аналізувати факти і вникати в їх суть. Не вникнувши в неї, не скажеш правильно фрази. Звичка говорити по тактах зробить ваше мовлення не тільки струнким за формою, зрозумілим за передачею, а й глибоким за змістом, бо змусить вас думати про сутність того, що ви говорите на сцені» [5, 96-97]. Станіславський мав на увазі, що слід виробляти навик логічного прочитання тексту; дивлячись у розмічений текст й, навіть читаючи його про себе, чути, як він звучить. Розглянемо конкретні приклади:

Паузи 3'єднувальні (/): У нас був дід/ дуже схожсий/на бога [4]. У неділю /перед богами горіла маленька синенька лампадка, /в яку завжди набиралось повно мух. Образ святого Миколая / також був схожий на діда,/ особливо коли дід часом /підстригав собі бороду і випивав перед обідом /чарку горілки з перием,/ $і$ мати не лаялась [4]. Як правило, паузи між реченнями виконують ті ж самі завдання, що й у середині речення, але бувають тривалішими.

Паузи роз'сднувальні (//): Він був письменний по-иерковному/ $i$ в неділю любив урочисто читати псалтир./ Нi дід, ні ми не розуміли прочитаного, /i це завжди хвилювало нас, як дивна таємниия,/ що надавала прочитаному особливого, небуденного смислу. // Мати ненавиділа діда і вважала його за чорнокнижника [4]./ Там, у льоху, в присмерку плигали жаби. Напевно, там водилися й гадюки. /// На погребні любив спати дід [4].

Люфтпаузи('): Звали нашого діда, як я вже потім довідавсь,' Семеном [4]. Найкращою рибою дід вважсв ' линину [4].

Психологічні паузи $<\ldots>$ ставляться там, де, за словами К. Станіславського, «...здавалося б, логічно й граматично неможливо зробити зупинки, там пї сміливо вводять психологічно...» [5, 97]. 3 нього можна було писати лицарів, богів, апостолів, великих учених чи сіятелів,- він годивсь $\leq \ldots>$ на все [4]. Oт тоді-то вперше в житті і вирішив я творити $\leq \ldots>$ добрі діла [4].

Пауза, що стоїть не на своєму місці, нівелює сенс усього речення. Перестановку пауз можуть собі дозволити актори в результаті великої попередньої роботи над образом і лише у тому разі, коли це допомагає розкрити суть образу через неправильне мовлення.
Важливу роль у логічному аналізі тексту має вживання розділових знаків.

Крапка показує завершеність думки, закінчення речення. Вона пов'язана із сольним пониженням голосу на ударному слові. Як правило, крапка вимагає порівняно довшої паузи, особливо коли збігається із завершенням думки. Найчастіше це роз'єднувальна пауза. Наприклад: Зрештою, мати крадькома таки знищила псалтир. Вона спалила його в печі по одному листочку, боячись палити зразу весь, щоб він часом не вибухнув i не розніс печі.///Любив дід гарну бесіду й добре слово [4]. Як бачимо, перед початком опису діда має бути «справжня» крапка, що демонструє завершення попередньої думки.

Однак частіше зустрічаються випадки, коли крапка в кінці речення передбачає розвиток думки в наступних реченнях. Голос знижується, але не падає різко донизу, як у попередньому прикладі: Найкращою рибою дід вважав линину.// Він не ловив линів у озерах ні волоком, ні топчійкою, а якось неначе брав їх з води прямо руками, як китайський фокусник [4].

Крапка з комою розподіляє і водночас об' єднує в одне ціле частини одного опису. Голос перед нею знижується, але не так сильно, як при крапці. Найпоширенішою помилкою під час читання крапки 3 комою є пониження голосу, як при крапці. Крапка 3 комою означає з'єднувальну паузу. Зазвичай така пауза коротша. Наприклад: Камель клекотів у нього в грудях, як лава у вулкані, довго $і$ грізно, $і$ дуже нескоро після найвищих нот; // коли дід був уже весь синій, як квітка крученого панича, вулкан починав діяти, і тоді ми тікали хто куди, а вслід нам довго ще неслися дідові громи і блаженне кректання [4].

Кома показує, що думка не завершена. Це з'єднувальна пауза, перед якою має бути підвищення голосу на наголошеному слові. Наприклад: ...великі соми вже скидались у Десні між зірками, / а ми все слухали, розкривши широко очі,/поки не повергались в сон у запатному сіні під дубами над зачарованою річкою Десною [4]. Ненаголошене слово, що стоїть перед комою, може стояти не обов'язково безпосередньо перед комою, але підвищення слова має бути на іменниках: Федосію я не молився, в нього була ще темна борода, а в руці гирлига, одягнена чомусь у білу хустку [4]. Перед протиставними сполучниками перед комою голос підвищується. Багато було різних гріхів $і$ багато кар, але ніхто їх чомусь наче і не боявся [4].

Кома «не читається», хоча за правилами пунктуації обов'язково вставляється. I саме тому, що 
душі в нього вистачило б на иілий океан, Васко да Гама часом не витримував иісї диспропориіі й топив свої кораблі в шинку [4]. Старший мій брат Оврам був давно уже проклятий бабою, і його гола душа давно летіла стрімголов з лівого верхнього кутка картини прямо в пекло за те, шо драв голубів на горищі $і$ крав у піст з комори сало [4]. Також не слід «читати» кому при дієприслівниковому звороті: Діда (мати божилася, що це правда) тримав у руках сам диявол за те, що він чорнокнижник $i$ що, читаючи по неділях волшебний псалтир,/ заклинав іï, і тому вона третій рік все хворіс,// що ту чорну книгу вона часто рвала нишком на шматки і розкидала у хліві, в кошарі, в гарбузах, у малині,/ а вони ніби зліталися самі до шкіряної палітурки [4].

Двокрапка зазвичай демонструє прагнення пояснити, уточнити, перелічити те, про що сказано перед нею. Двокрапці має передувати сполучна логічна пауза. Як правило, перед двокрапкою голос на ударному слові, яке стоїть перед ним, трохи знижується, хоч і значно менше, ніж на крапці. Головна помилка при читанні двокрапки полягає в тому, що голос занадто сильно знижують і виникає інтонація, подібна до інтонації при крапці. Варто стежити за тим, щоб такого не відбувалося, адже головне це те, що міститься в реченні після двокрапки. В намій сім'ї майже всі були грішні://достатки невеликі, серия гарячі, роботи і всякого неустройства тьма, а тут ще й фамільна приверженість до гострого слова, / томухоч й думали інколи про рай, все-таки більше сподівалися на пекло внизу картини. [4]. У деяких випадках двокрапка може бути прочитаною і з підвищенням голосу на ударному слові, що передує йому. Коли ж дивлюсь: баба снує коло моркви, дідова мати [4].

Tире - розділовий знак, що вказує на наявність протиставної інформації. Досить часто тире демонструє з'єднувальну інтонацію й вимагає підвищення голосу на слові, що передує розділовому знакові. Вириваю одну - мала. Гичка велика, а сама морквина дрібненька, біла і зовсім

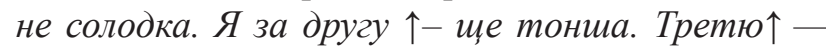
тонка [4]. У цих прикладах голос підвищується на слові, що стоїть перед тире, а на слові після тире - понижується.

Інтонація знака оклику передбачає енергійне виділення наголошеного слова за допомогою його підвищення. Знак оклику покликаний виказувати інтонацію захоплення, радості, злості, обурення, образи, протесту тощо. Окличне речення може висловлювати будь-який намір або його сло- весну дію: прохання, благання, загрозу, вимогу, наказ, звинувачення, похвалу - будь-яке сильне почуття. Наприклад: До чого ж гарно і весело було в нашому горо́di! А сад було як зацвіте весною! А що робилось на початку літа! Огірки ивітуть, гарбузи ивітуть, картопля ивіте. Цвіте малина, смородина, тютюн, квасоля. А сонящнику, а маку, буряків, лободи, укропу, моркви! Чого тільки не насадить нама невгамовна мати [4]. Уривок насичений окличною інтонацією захоплення, радості, оптимізму.

Знак питання - ознака питального речення. Інтонація передається підвищенням голосу на наголошеному слові. У кінці питального речення голос знижується. Як відомо, в українській мові $\epsilon$ два типи питальних речень: 3 питальним словом і без нього. У реченні без питального слова слід різко підвищувати голос на наголошеному слові. Потопають, чув? [4]. Кажи, будеш плигати поміж косами? [4]. У питальному реченні 3 питальним словом наголос на питання має бути дещо слабший, та все ж важливо запам'ятати, що в питальному реченні після слова, що містить запитання, вже не може бути підвищення голосу, всі інші слова звучатимуть нижче від наголошеного слова. Інтонація знака повинна містити активне бажання отримати відповідь на запитання, що ставиться. Станіславський зауважив, що знак питання зобов' язує слухачів до відповіді, тож при читанні питальних речень слід звертати енергетику до аудиторії слухачів.

- A хтоо вона, діду, людина ота? Звідки вона?

- А бог ї̈ знає, хіба я знаю?.. Ну, чого стоїи як укопаний? - звертався дід до коня, сідаючи на воза. [4].

Три крапки $<\ldots>-$ розділовий знак, яким позначають на письмі незакінченість або перерваність висловлення, а також пропуски у тексті. Може бути у кінці сюжетного уривка тексту чи навіть наприкінці художнього твору (відкритий фінал, незавершеність думки тощо). На думку К. Станіславського, під час читання трикрапки «наш голос не піднімається вгору і не опускається вниз. Він тане і зникає, не закінчуючи фрази, не опускаючи іiї на дно, а залишаючи ії висіти в повітрі» [4]. А-а, хіба ще риба! Казна-що, не риба. От колись була риба, щоб ви знали. Ото з покійним Назаром, хай изарствує, як підемо було... Тут дід заводив нас у такі казкові нетрі старовини, що ми переставали дихати... [4].

Коли трьома крапками позначена психологічна пауза, то наголоси на словах, що стоять перед 
розділовим знаком, можуть бути дуже різноманітні за висотою. Тут усе залежить від волі виконавця, від сценічного завдання, оцінок, видінь, словесних дій. Горобичі иъвірінькають. Батько труну струже. Сніг розтає. Із стріх вода капле, із стріх вода капле... Так я тоді зліз на купу лози та й ну гойдатися, та й ну гойдатися, та й ну гойдатиcя.[4].

Уривки, що включають пряму мову персонажів, потребують особливої уваги, адже передають той неповторний колорит персонажів, від чиєї особи йде оповідь. Колоритними $є$ постаті баби Марусини, з вуст якої звучали прокльони, «без прокльонів вона не могла прожити й дня. Вони були їі духовною їжею». [4]. Мовлення діда пересипане іронічністю, спокоєм, розважливістю: Та не гавкай хоч ти мені. Чого б ото я гавкав,жалівся дід. [4]. Пряма мова від імені батька має звучати гордо, розважливо, материна - спокійно, дещо приглушено, передаючи природну доброту й спокій. Як відомо, в кіноповісті «Зачарована Десна» особистість автора й виконавця немовби збігаються, даючи змогу в більш природній манері, 3 використанням розмовного стилю, подавати літературний матеріал. У тексті діють двоє персонажів - маленький безпосередній Сашко, від імені якого, власне, плине оповідь, та зрілий, дорослий оповідач Олександр, який розповідає, аналізуючи. Текст, переданий від першої особи, тож якраз і призначений допомогти у створенні образу, вдачі, включати певне узагальнення.

Подаємо демонстраційний приклад логічного аналізу тексту:

Де ж не взявся/рудий бичок Мина, що любив дукатись, 'бо ріжки свербіли,/ а тут ще до боків кізяки примерзли і живіт лоскотали. // Так він тодi,'відчинивщи хвіртку отими рогами, що так засвербіли, $i \uparrow / /$ - гуру до Захарка!/ А той почав лаяти проклятого Мину і з криком:// «Рятуйте,/ кишки випускає!»//—упав у калюжу. $\downarrow / /$ Ой, як не побачить наш вірний собака, шо Піратом звався, / як дукає Мина коваля Захарка,/ як торохтять відра,/кудкудачуть кури, / батько труну робить, / із стріх вода капле, та як не возгавкає! //Затахкали качки, засичали гуси, полякались кури, горобиі хто куди киш! $\uparrow$ А він, клятий, ой, як не підскочить,/ i, забувши, певно, шо на прив'язі, /кинувсь доганяти Мину, і протяг на дроті через двір' крещендо таку гучну ноту,/ що дріт обірвався!^// $<\ldots>$ На якусь мить настала тиша. $\downarrow[4]$.

Логічний аналіз тексту - як початковий етап відтворення авторського задуму надає розповіді переконливості, допомагає заразити слухачів своїми переживаннями й думками, робить мистецтво дієвим і значимим. А от засоби впливу на аудиторію мають бути підпорядковані засобам виразності, якими володіс актор: вони не виходять за рамки словесної дії. Тож це вимагає особливого відпрацьовування всіх компонентів словесної дії, вимагає ретельної підготовки через постановку активних завдань, через підтекст, через лінію думки й бачення. Сам процес спілкування, який є основою дієвості й дохідливості слова, необхідний для актора-початківця.

Практичні заняття з логічного аналізу тексту повинні мати практичне значення, кожне виведене правило слід акцентувати конкретними прикладами і виробляти навички й доводити їх до автоматизму. Засоби впливу на аудиторію мають бути підпорядковані засобам виразності, що їх повинен набувати актор.

\section{Джерела та література}

1. Гладишева А. О. Сценічна мова. Київ: КІТМ, 1999. 204 с.

2. Запорожец Т. И. Логика сценической речи. Учебное пособие для театр. и культ. просвет. заведений. Москва: Просвещение, 1974. 218 с.

3. Петрик Т.Д. Методологічні аспекти формування навичок сценічного читання в роботі над літературним твором. URL: http://web. znu. edu. ua/herald/issues/2010/ ped_2010_2/100-106. pdf, 2010.

4. Довженко Олександр. Зачарована Десна. Кіноповість.. УКРЛІБ / Бібліотека української літератури. URL: https://www. ukrlib. com. ua/books/printit. php?tid=866

5. Станиславский К. С. Собрание сочинений / К. С. Станіславський. Т. 3. Москва, 1957. С. 96-97.

\section{Referens:}

1. Gladysheva, O. A. (1999). Scenic language. Kiev: KITM. 204 [in Ukranian].

2. Zaporozhets, T. I. (1974). The logic of the stage speech. Educational manual for theater. and the cult. lumen routine. Moscow: Prosveshchenie. 218 [in Russian].

3. Petryk, T. D. (2010). Methodological aspects of forming stage writing skills in work on a literary work. URL: http: //web. znu. edu. ua/herald/issues/2010/ped_2010_2/100-106. pdf [inUkranian].

4. Alexander Dovzhenko. Enchanted Desna. Film poetry. Electronic resource of UKRLIB / Library of Ukrainian Literature. URL: https: //www. ukrlib. com. ua/books/printit. php? Tid $=866$ [in Ukranian].

5. Stanislavsky, K. S. (1957) Assembly of accomplishments. T.3. Moscow, 1957. 96-97 [in Russian]. 